\title{
Mangroves Response to Climate Change: A Review of Recent Findings on Mangrove Extension and Distribution
}

\author{
MARIO D.P. GODOY and LUIZ D. DE LACERDA \\ Instituto de Ciências do Mar, Universidade Federal do Ceará, Laboratório de Biogeoquímica Costeira, \\ Av. Abolição, 3207, Meireles, 60165-081 Fortaleza, CE, Brasil \\ Manuscript received on February 2, 2015; accepted for publication on February 26, 2015
}

\begin{abstract}
Mangroves function as a natural coastline protection for erosion and inundation, providing important environmental services. Due to their geographical distribution at the continent-ocean interface, the mangrove habitat may suffer heavy impacts from global climate change, maximized by local human activities occurring in a given coastal region. This review analyzed the literature published over the last 25 years, on the documented response of mangroves to environmental change caused by global climate change, taking into consideration 104 case studies and predictive modeling, worldwide. Most studies appeared after the year 2000, as a response to the 1997 IPCC report. Although many reports showed that the world's mangrove area is decreasing due to direct anthropogenic pressure, several others, however, showed that in a variety of habitats mangroves are expanding as a response to global climate change. Worldwide, pole ward migration is extending the latitudinal limits of mangroves due to warmer winters and decreasing the frequency of extreme low temperatures, whereas in low-lying coastal plains, mangroves are migrating landward due to sea level rise, as demonstrated for the NE Brazilian coast. Taking into consideration climate change alone, mangroves in most areas will display a positive response. In some areas however, such as low-lying oceanic islands, such as in the Pacific and the Caribbean, and constrained coastlines, such as the SE Brazilian coast, mangroves will most probably not survive.
\end{abstract}

Key words: climate, mangrove, limits, migration.

\section{INTRODUCTION}

Mangroves are forest formations estimated to cover from 12 to 20 million hectares worldwide (FAO 2007). Mangrove distribution restricts to the intertropical zone, between $30^{\circ} \mathrm{N}$ and $30^{\circ} \mathrm{S}$ latitudes and roughly follows the $20^{\circ} \mathrm{C}$ isotherm of seawater temperature, which in turn depends on sea currents and therefore can vary between winter and summer (Spalding et al. 1997).

Correspondence to: Luiz Drude de Lacerda

E-mail:1drude@pq.cnpq.br
Natural coastal habitats such as salt marshes, mangroves, coral and oyster reefs, and seagrass beds, buffer coastlines from erosion and inundation, providing important protective services. One of the many advantages of nature-based protection is that those same habitats also provide other benefits, including nursery grounds for commercially and recreationally valued species, landing point for migratory birds, filtration of sediment and pollutants, and carbon storage and sequestration (FAO 2007, Scavia et al. 2002). 
The social values of these services are broad and include those reflected in markets, such as diminishing the costs of natural disasters, maintaining human health and livelihoods through improving food security, and sustaining cultural and aesthetic values. Based on biodiversity alone, mangrove forests provide at least US \$1.6 billion each year in ecosystem services and support of coastal livelihoods worldwide (Polidoro et al. 2010). However, by occupying the coastline, which includes areas of high population density, mangroves are under constant pressure from urban and agricultural expansion, diverse industrial activities, hydrological changes of river basins, spills of chemicals and eutrophication, despite its great importance in sustaining the coastal zone (Medina et al. 2001, Valiela et al. 2001, USGS 2004, Long et al. 2014).

Studies to assess the extinction risks of mangrove species found that 70 species of mangroves, mostly in Asia and Oceania, stand at elevated threat of extinction and could disappear within the next decade. This loss will have devastating economic and environmental consequences for coastal communities due to the importance of these species for the livelihood of indigenous populations (Polidoro et al. 2010).

Climate change has been receiving increasing awareness relative to its potential impacts on the coastal zone, generally associated with sea level rise, increase in air and water temperature, increase in atmospheric $\mathrm{CO}_{2}$, alterations in the quantity and quality of the continental runoff and changes in the frequency and intensity of extreme meteorological events (Alongi 2008). Because of their location at the continent-ocean interface, mangroves are more likely to respond to these hazards resulting from global climate change. All of these will, to some extent, alter primary and secondary productivity and respiration of mangroves and their associated biocoenosis, and the transport of materials to adjacent terrestrial and marine ecosystems.
Latest estimates suggest that it is very likely that sea level will rise in $95 \%$ of the coastal areas worldwide, with changes varying from $0.26 \mathrm{~m}$ in the more optimistic models to $0.98 \mathrm{~m}$ in the most pessimistic projections (IPCC 2013). The past 20 years have witnessed a global mean sea level rise of $3.23 \pm 0.4 \mathrm{~mm} \mathrm{yr}^{-1}$. However, high regional variability stretches this mean one order of magnitude; in fact the western coasts of North America Western witnessed a fall by $1-2 \mathrm{~mm} \mathrm{yr}^{-1}$, while rising by $5-20 \mathrm{~mm} \mathrm{yr}^{-1}$ in SE Asia and the Western Pacific (Nicholls and Cazenave 2010). Best-case scenarios suggest an average sea level rise by 2081-2100 of $40 \mathrm{~cm}(26-55 \mathrm{~cm})$ (whereas worst-case scenarios anticipate an average of $63 \mathrm{~cm}$ (45-82 cm); relative to $1986-2005$. This rise will not be uniform across regions and about $70 \%$ of the global coastline will experience a change of $\pm 20 \%$ of the global mean (Pachauri 2015). Therefore, mangrove response to these changes will likely to vary regionally.

Although changes in sea levels are the most obvious threat to mangroves, for an individual stand, the relative mean sea level (the difference at that point in space and time between the mean global sea level and the local isostatic change due to glacial rebound) (Nicholls and Cazenave 2010) will be the key variable inducing the specific mangrove response. Direct human drivers that affect the sediment budget of mangroves and thus the rise or fall of the mangrove substrate level (e.g. land-use changes, dams, pumping of groundwater, petroleum and gas exploration in deltas, aquaculture) will also influence mangrove response to climate changes, since they result in increasing surface and belowground water salinity, the hydrodynamics of river basins, the amount of sediment reaching the coast, and therefore the erosion-sedimentation equilibrium of the coastline; as well as the mobilization of nutrients and pollutants in estuaries (Scavia et al. 2002, Godoy and Lacerda 2014, Lacerda et al. 2013). In summary, 
worldwide, the final impact on mangroves varies according to location, and results from a complex interaction between rising sea level and changes in the watershed, including the decrease of the continental runoff due to altered rainfall regime (Dai et al. 2009).

Within this context, this article aims to analyze recent results from studies done around the world over the past 25 years, on the long-term observation of mangrove's response to anthropogenic induced global climate change. This review takes into consideration case studies and predictive modeling, published between 1991 and 2015, on mangrove forest area and shape changes, latitudinal migration and displacement, along the continent-ocean interface. It is important to note, that although studies on potential or expected response of mangroves to climate change are relatively abundant, we restricted our analysis on actual observed responses. Furthermore, not included in this review are those studies, which focused on the changes in biodiversity and/or in the physiology of mangroves or alterations of environmental biogeochemical processes, although both may be a consequence from changes in the mangrove distribution due to the unique biochemistry of the mangrove environment.

\section{RESULTS}

Based on the number of published articles, found during our survey, on mangrove forest area and shape alterations associated with climate change, there is a growing interest since 1991, when one of the first published paper on the subject appeared (Ellison and Stoddart 1991). However, it is important to note that mangrove response to global changes in the past, such as sea level rise due to deglaciation, has been a source of important data (Castro et al. 2013). The result of Ellison and Stoddart (1991) study paleo-ecology research is frequently in use to support models of mangrove response to anthropogenic climate change. Extensive discussions on the topic can be found, for example, in Snedaker et al. (1994) for the Florida coast in the USA; Behling et al. (2001, 2004), Toledo et al. (2008a, b) and Guimarães et al. (2010) for the north coast of Brazil; Tessler and Mahiques (1998), Bastos et al. (2010), Barth et al. (2006) and Cunha-Lignon et al. (2009) for Southeastern Brazil and Schaeffer-Novelli et al. (2002) for a global review on the interactions between mangroves and sea levels.

The interest in the subject of mangrove response to global climate change began to increase in the early 2000s, probably because of the 1997's IPCC report on climate change (IPCC 1997) and of the previous report from UNEP-UNESCO on the expected impact of climate change on mangroves, resulting from the 1992 Rio Conference (UNEPUNESCO 1993). Considering only the responses related to geographical expansion and changes in area cover, in the first decade (1991-2001) of the studied period, there were only 16 published papers on the subject. In the following decade (20022012), there was an increase of over 3-times, with the publication of 58 studies. More recently, the subject raised attention worldwide and at least 13 papers appeared in 2013 alone. Up until now, 12 papers have appeared in 2014-15, on the specific aspect of the mangrove response to climate change. Concerning the country of origin of each paper, the United States, Brazil and Australia have the largest number of published studies, with $34 \%, 16 \%$ and $15 \%$ of papers, respectively. The Asian continent, despite not having any individual country with a large number of publications, has, as a whole, a large importance when viewed as, with $14 \%$ of articles distributed in eight countries. The other studies, about $20 \%$ of the total, were global reviews or multinational publications.

All these countries have significant mangrove areas, thus it is understandable that they carry out the greatest amount of studies. In the case of the United States and Asia, most of the mangroves are located in large populated areas frequently affected 
by severe storms and hurricanes, extreme climatic events, which are more likely to be affected by global climate change, and, therefore, with potential significant impacts on mangroves. Furthermore, some of these regions are island regions or lowlying peninsulas and deltas, which are much more susceptible to sea level rise, which makes the preservation and understanding of mangroves an even more urgent matter.

In the last 50 years, between $30 \%$ and $50 \%$ of the mangrove forests have disappeared, this loss is continuing and in some places, it is even accelerating. The rate of coastal ecosystems annual loss is 4-times the rate of tropical forest loss (Copertino 2011). Mangroves of the Pacific islands are the most at risk due to erosion and deforestation. Mangroves along mainland Asia also witness severe pressure from their fast conversion into urban and agricultural development. In this scenario, climate change apart from promoting specific pressure on mangroves could maximize the impacts from other anthropogenic drivers.

Some recent reviews on the environmental pressures on mangroves due to climate change suggest that important threats to mangroves are mostly due to changes in salinity, wave regime, and the quantity and quality of the sediment loading (Giri et al. 2011), which may be further enhanced by increasing the frequency of extreme climatic events. For example, based on the IPCC maximum sea level rise scenario Gilman et al. $(2006,2007)$ predicted an up to $13 \%$ loss for Pacific island mangroves by the year 2100. Similarly, Alongi (2008) arrives at a global loss rate of mangroves related to climate change of about $10-15 \%$.

Laurence et al. (2011) in a study about the most fragile ecosystems in Australia, pointed out that mangroves are a vulnerable ecosystem due to their narrow environmental tolerances, their geographically restricted distribution, their proximity to dense human populations in coastal zones, their patchy and fragmented location in the country and their reliance on a few key framework species. The authors believe that the increase in storm intensity and the likelihood of the mangroves being squeezed between human land-uses or topography on the landward side, and rising sea levels on the seaward side, is the major threat to these forests. Other threats indirectly related to climate change are changes in salinity and hydrology. Mangroves that cannot keep up with rising sea level or do not have space to migrate inland will suffer the risk of drowning (Gilman et al. 2008).

Some researchers however, have found that not all mangroves will respond negatively to a climate change scenario. Recent studies showed that in many locations mangrove vegetation are expanding their poleward limits. Cavanaugh et al. (2014) observed that mangroves are expanding northward, from their original latitudinal limit along the east coast of the USA, and further suggested that this expansion is associated with the decrease in the frequency of discrete cold events $\left(-4{ }^{\circ} \mathrm{C}\right)$ due to recent global warming. Along this part of the North American coast, the spatial extension of mangrove forests has doubled, relative to the area recorded during the 1980's. These events would freeze and kill mangrove vegetation that crossed the poleward limits during the warmer periods of the year. However, these events are becoming less frequent and, consequently, mangroves are able to expand beyond their common territory. Studies in the Gulf coast in Louisiana in the USA also showed a mangrove expansion northwards with Avicennia germinans colonizing areas previously occupied by salt marshes, following two decades of warmer winters (Perry and Mendelssohn 2009).

In the Florida Keys, Stevens et al. (2006) showed that, mangroves are expanding since the last harsh winter and occupying places where salt marshes previously existed. Several other studies showed that, due to sea level rise, the mangroves have started to replace the original inland vegetation in several islands along the 
Florida coast. In Sugarloaf Key, for example, the pine tree vegetation declined from an initial 88 ha before 1935 , to 30 ha by 1991 , partially replaced by the white mangrove $A$. germinans. The pine tree mortality occurred in low elevation areas, and probably resulted from both groundwater and soil water salinity increase. Higher water salinity appeared in areas of rapid pine forest reduction and the pines sampled in these areas exhibited higher physiological stress (Meeder et al. 1993, Ross et al. 1991, 2009). In the Atlantic coast of Florida, in the Everglades, Rhizophora mangle L. has expanded landward more than 1,000 meters into marshlands previously occupied by Cladium and Eleocharis (Ross et al. 2000), possibly in response to higher sea levels, changing groundwater levels, and shifting fire regimes (Smith et al. 2013). On the other hand, under carbonate settings with little or no allochthonous sediment input, such as on small, low-lying islands of the Caribbean and the Keys region, with little land area and an unsuitable land surface elevation gradient, mangroves cannot cope with sea level rise (Ellison and Stoddart 1991).

McKee et al. (2004) showed that an extensive dieback of salt marsh occurred throughout the Mississippi River deltaic plain in the year 2000. According to these authors, the phenomena affected more than 100,000 ha, with 43,000 ha severely damaged. Parts of these areas were colonized by mangrove vegetation, mostly $A$. germinans. Doyle et al. (2010) used mathematical modeling to predict how sea level change would affect the coast of the Gulf of Mexico and found that mangrove forests in the region showed a scenario of large expansion landward. This would result in a shift in the proportion of forest habitats with a loss of nearly 39,728 ha of freshwater forest and a gain of 21,784 ha of mangroves along the eastern Gulf States and a loss of 186,863 ha of freshwater forest but a small gain of 1,050 ha of mangroves in the western Gulf States.

Similar landward expansion occurred at Magdalena Bay, Baja California, on the Pacific coast of Mexico. López-Medellín et al. (2011) reported a $20 \%$ increase in mangrove extent through landward migration into halophytic shrub land, associated with sea level rise, and particularly pronounced during El Nino seasons. The effects of strengthening of the El Niño, suggested by some global climate models (IPCC 2013) could accelerate mangrove expansion, as suggested by studies in this and other areas.

Another study from Baja California Sur, also reported an increase in mangrove area associated with sea level rise. Hak et al. (2008) found an increase of mangrove area of 7,575 ha between the years of 1986 and 2001 . About $80 \%$ of the new mangrove area was colonized by $A$. germinans, occupying 6,056 ha and most of this increase occurred in the Magdalena Bay region.

In the southern limit of mangroves along the Western Pacific Ocean in Peru, the cold and arid conditions hinder mangrove expansion south of a small stand of mangrove vegetation in the Piura River Estuary (Clüsener and Breckle 1987). Mangroves in this estuary have expanded to 38 ha in the north arm and 9 ha in the south arm of the estuary, lining $9.5 \mathrm{~km}$ of shoreline and is the southernmost confirmed mangroves on the west coast of South America (Saintilan et al. 2014), however, similar to other areas, such as the South Atlantic latitudinal limit, evidence is still scarce to support poleward expansion due to global climate change.

Studies carried on in Australia and other Pacific countries have shown an increase in mangrove areas due to the influence of climate change on key mangrove growth controlling parameters. Eslami-Andargoli et al. (2009) reported landward mangrove expansion over salt marsh areas in Moreton Bay, between 1972 and 2004. They also found a significant relationship between rainfall patterns and the rate of mangrove expansion. According to these authors, mangroves showed a larger expansion in area during the rainy years between 1972 and 1990 than during the drier years 
from 1990 and 2004. The higher supply of fluvial sediments, nutrients, lower exposure to sulphates and reduced salinity could be responsible for this larger expansion in wetter years.

A study by Williamson and Boggs (2011) in the Kakadu National Park, North Australia, found that, despite the damage caused by a cyclone in the study area, all mangrove swamps showed a landward growth over a 30 -year period. This expansion rate was higher in swamps that have undergone hydrological changes due to engineering works but also occurred in other locations, without direct anthropogenic influence. Engineering works, such as dams, wave breakers and other coastal interventions are capable of maximizing the effects of climate change on mangroves (Lacerda et al. 2007, 2013).

A study conducted by Wilton (2002) in nine different locations in Australia revealed that, in almost all of the studied sites, the expansion of mangroves occurred at the expense of some other type of vegetation. From the 1940s to the 1990s, only $42 \%$ of the original area of salt marsh in that region remained, whereas mangroves replaced 58\% of the existing salt marsh area, in 1990.

In New Zealand, a study conducted at the Firth of Thames by Lovelock et al. (2010) showed an accretion of mangrove forest of $1 \mathrm{~km}$ seaward over 50 years (an average of $20 \mathrm{~m} \mathrm{y}^{-1}$ ). There were two major periods of mangrove expansion, one in 197881 and another in 1991-95. Both periods coincided with periods of sustained El Niño activity, an atmospheric phenomenon highly influenced by global climate change. Another study from Lovelock et al. (2007) showed that, in two other estuaries in New Zealand, fertilization and high sedimentation rate, probably induced by stronger El Niño, favored mangrove area increase.

Stokes et al. (2010) carried out a study in two embayments of Tauranga Harbour in New Zealand and found that spreading mangroves had become a coastal management issue even under a temperate climate environment. The authors found that since the $1960 \mathrm{~s}$, mangrove habitats within both embayments have increased their intertidal coverage by around 15 ha and that local residents are currently clearing the seedlings. However, survival rates of up to $80 \%$ suggest that in the absence of human intervention, continued expansion of mangrove forests would be likely.

Asia is the continent with the largest mangrove area in the world and it is also where the mangrove forest are more diverse (FAO 2007), but lack of data and extensive clearing could hamper the studies on this region. In a review on mangrove expansion beyond their poleward limits, Saintilan et al. (2014) reported that historical data in Japan, for example, are insufficient to confirm mangrove expansion. Saintilan et al. (2014) also noted that the delimitation of mangrove limits in China and Taiwan are complicated due to extensive clearing. However, in the Zhanjiang Mangrove National Nature Reserve on the Leizhou Peninsula of Guangdong Province, China, one of the few locations where mangrove and salt marshes co-exist in near natural state, mangroves within this reserve have expanded fourfold, including encroachment on salt marsh area.

A study done in the Philippines showed that, between 1990 and 2010, there was a decrease of 28,172 ha of mangrove forest, about $10 \%$ of the mangroves in the country, with the driving force behind this decrease in several regions being the expansion of aquaculture and mangrove wood extraction. However, the largest loss of mangroves occurred due a typhoon in 1990; however, his area showed signs of recuperation after the occurrence (Long et al. 2014). Human induced land-use change were also indicated as the major drivers of mangrove area decrease in Southeast Asia and Vietnam (Nguyen 2014) mainly due to clearing for areas for urban and rural expansion and for aquaculture, this is also true for other Asian countries like Myanmar and India (Rao et al. 2013, Rahu et al. 2012). Therefore, 
it is very difficult to monitor mangrove area changes in the Asian continent without the interference of direct human drivers.

Notwithstanding, at the Sundarbans, one of the largest mangrove forests in the world located along the Indian and Bangladesh coast, mangroves are disappearing at fast rates due to the drowning of the deltaic island, over the past three decades (Shearman et al. 2013). Subsidence, a decreasing in sediment transport from the Ganges and other rivers to the sea due to damming, and rising sea level, resulted in a dramatic decline in mangroves growing on islands, particularly in the central and eastern sectors of the Sundarbans (Rahu et al. 2012). In other river deltas, sea level rise, storms, and cyclones enhanced subsidence and declines in sediment supply, resulting in a landward migration of mangroves but with a net contraction (Alongi 2015).

Africa is where $20 \%$ of the world's mangroves are located, according to Taylor et al. (2003). Mangrove ecosystems of eastern Africa are well studied with 265 published papers between 1950 and $2000,92 \%$ of those are centered in Kenya. This information is often not disseminated and the major reason is that the findings are generally confined to their countries of origin due to the numerous different national languages in the region. Overall, mangroves in almost every country in East Africa are decreasing due to human activities such as logging for fuel and house building, urban expansion, salt and shrimp production.

Di Nitto et al. (2014) simulated landward migration of mangroves in the Gazi Bay, Kenya, until the year 2100. The produced scenario showed that mangroves under low to medium sea level rise could shift without significant losses. However, under a maximum sea level rise scenario further landward migration would be obstructed by a strong increase of the topographical gradient.

South Africa is the southernmost area in Africa and $40 \%$ of its estuaries have lost their mangroves forests since 1982, resulting in only 24 estuaries with pristine mangroves today (Adams et al. 2004, Rajkaran et al. 2009). Their fragmented distribution pattern makes South African mangroves highly vulnerable to extreme events. According to Quisthoudt et al. (2013) one sea storm, causing estuarine mouth closure and prolonged inundation of intertidal areas could cause the loss of mangroves in a whole estuary, turning them particularly vulnerable to the increase in the frequency and intensity of extreme climatic events associated with climate change.

Notwithstanding the general decrease in mangrove areas due to direct human pressure, reports from South Africa have also shown an increase of mangrove area in protected areas (Taylor et al. 2003). Saintilan et al. (2014), showed that mangrove area in the country has increased in $40 \%$, within the past three decades with the largest expansion occurring in the Umhlatuze estuary with an increase from 197 ha to 489 ha over new sedimentary deltaic areas in that estuary (Bedin 2001, Ward and Steinke 1982).

Brazil is home to the second largest mangrove area in the world and Brazilian mangroves are under increasing pressure from a combination of human activities such as increasing coastal development, agricultural run-off, pollution and intensive aquaculture (Santos et al. 2014, Spalding et al. 2010). However, contrary to most countries harboring mangroves, in Brazil this ecosystem is considered as permanent preservation forests by the environmental legislation.

The Amazon Region has one of the largest macrotidal mangrove coasts of the world, with almost 7,600 km² (Souza Filho 2005). Within this region at Bragança, severe coastal erosion induced a shoreline retreat of $32 \mathrm{~km}^{2}$ between the years of 1972 and 1998 and resulted in a mangrove area loss of $12 \mathrm{~km}^{2}$ (Souza Filho and Paradella 2003). According to the study, the causes of the dramatic changes in the Bragança coastal plain are speculations due to the lack of historical series on 
wind, waves, and tidal currents data, but may be associated with increasing ocean forcing on the continental shelf along this section of the Brazilian coast (Dias et al. 2013).

Another study done in the same region showed that despite measured reduction in mangrove coverage along the coastline, there was an active growth of mangroves in topographically higher plains previously occupied by grasses and herbs. This upland vegetation occupied an area of $8.8 \mathrm{~km}^{2}$ in 1972 and reduced its cover to $5.6 \mathrm{~km}^{2}$ in 1997, being substituted by mangroves. A linear extrapolation of the process showed that the total area of high plain vegetation would be covered by mangrove in 2035 (Rubén et al. 2002).

Object-based approaches and SAR data for mapping and detecting changes in the extent of mangroves along the coastline southeast of the Amazon mouth, known as the Amazon Macrotidal Mangrove Coast (AMMC), showed that over a 12 year period (1996-2008), the total area of mangroves increased by $718.6 \mathrm{~km}^{2}$ from $6,705 \mathrm{~km}^{2}$ to $7,423.60$ $\mathrm{km}^{2}$, with $1,931 \mathrm{~km}^{2}$ of expansion and $1,213 \mathrm{~km}^{2}$ of erosion noted and $5,493 \mathrm{~km}^{2}$ remaining unchanged in extent. The observed expansion of large mangrove areas in the AMCC seems typical of this region (Nascimento Jr et al. 2013).

In one of the few other large continuous extensions of mangroves in the world, the Gulf of Papua in Papua New Guinea, Shearman (2010) showed a reduction in the mangrove area from 1973 to 2002. In the Sundarbans in Bangladesh and India another region of large mangrove extension, the total forest areas have remained unaltered during the same period (Giri et al. 2007, 2008). However, both studies restricted their mapping to the seaward fringe, failing to account for any expansion landward, which seems typical of these large stands of mangroves responding to sea level rise, as shown for the AMCC in Brazil.

Studies carried out on the northeastern coast of Brazil, showed that several areas of mangrove forests located in estuaries are increasing. Maia et al. (2006) compared, by means of remote sensing, the present extension of mangrove forests with maps published previously that used radar materials and aerial photographs, in 1978 (Herz 1991), and showed an increase in mangrove area from $444 \mathrm{~km}^{2}$ to $610 \mathrm{~km}^{2}$, approximately $37 \%$ during a period of 25 years, although the different methodology and instrumentation probably overestimated this expansion.

A study done in the Jaguaribe River, the largest river in the state of Ceará, showed an increase of 24.15 ha in the area of islands within the estuary, between the years 1992 and 2003, by means of similar satellite image analysis of the entire period. These islands are rapidly being colonized at present, by mangrove vegetation (Fig. 1). The increased rate of sedimentation in the estuary caused by landuse drivers is aggravated by the decrease in river flow caused by damming but also by the decrease in rainfall over the basin caused by global climate change (Godoy and Lacerda 2014). Furthermore, the residence time of water and materials in the estuary is increasing due to the increasing oceanic forcing in the continental shelf, because of excess heat accumulating in the South Atlantic due to global warming (Dias et al. 2013, Lacerda et al., 2013).

A study conducted by Lacerda et al. (2007) on the mangrove expansion at the Pacotí River estuary, in the metropolitan region of Fortaleza, state of Ceará, showed that, in addition to colonizing old salt pits, mangroves also grew on recently enlarged estuarine islands and beaches. According to the authors, between 1958 and 1999, six new islands emerged in the estuary. These new areas were quickly occupied and secured by mangrove trees, which increased the areal coverage from 71 ha in 1958 to 142 ha in 1999. After that period, mangrove areas continued to expand, reaching 144 ha in 2004. In both cases, it is difficult to differentiate impacts caused by local human activities and global environmental changes, since the estuary responds 

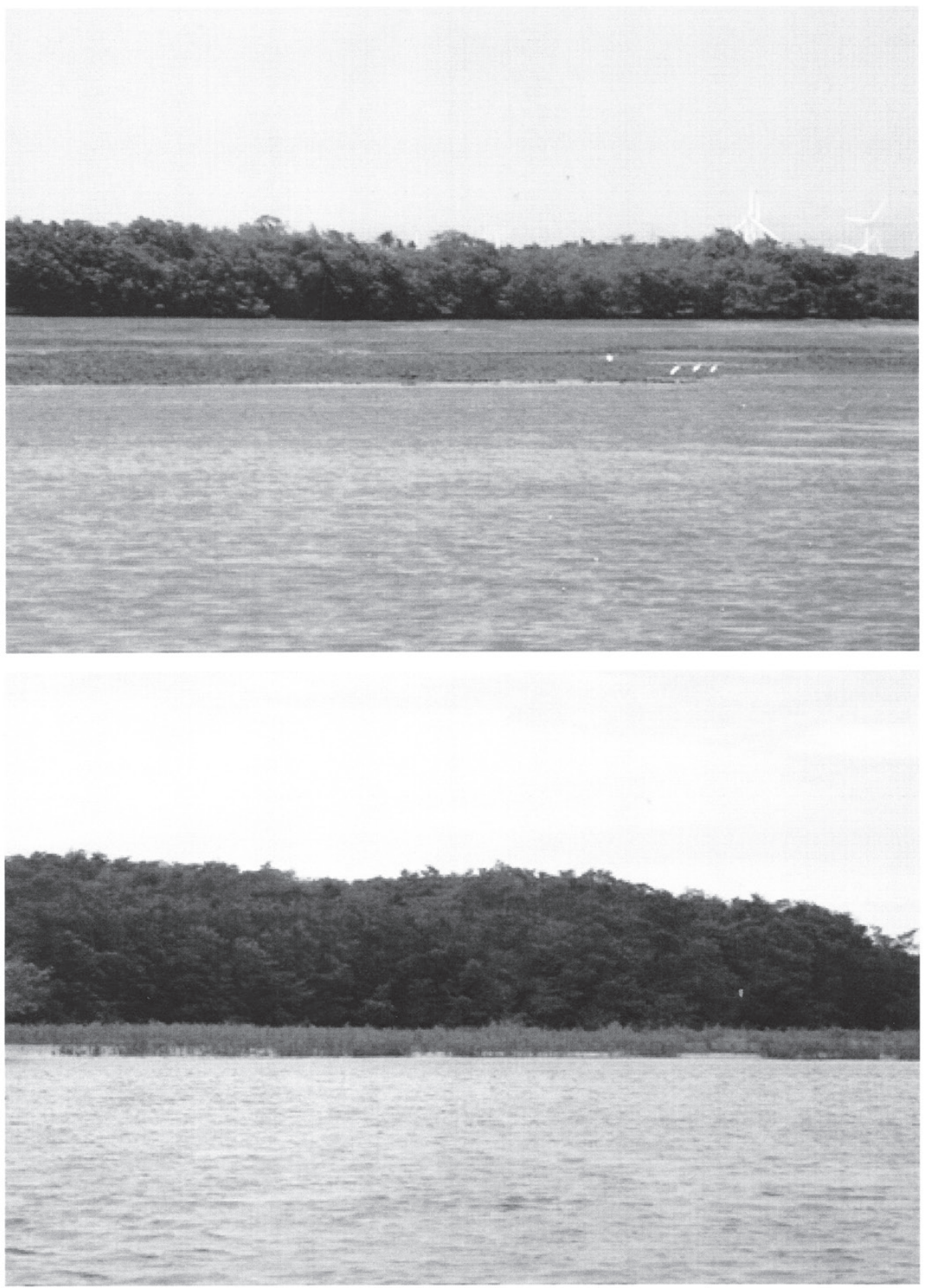

Figure 1 - Mangrove growth in an island located in the Jaguaribe River, sand beach in 2009 (Top) and the same beach in 2010, now colonized by established mangroves seedlings (Bottom).

to alterations occurring throughout its watershed, in particular the damming of rivers. River damming is a very important feature in the state of Ceará, this region is located in the semi-arid portion of Brazil and, due to this climatic characteristic, and most of the rivers have some sort of water reservoir for human consumption. According to the company responsible for monitoring the water level of the dams, there are 149 monitored reservoirs throughout the region (COGERH 2015).

Studies carried out in twelve estuaries in the state of Ceará showed that, of all studied areas, nine are showing an increase in mangrove forest area; however, climate change alone is not enough 
to explain these changes. One of the studied areas was the Aracatimirim River estuary (Fig. 2), this estuary showed an increase of more than $400 \%$ in mangrove area between 1993 and 2008. Most of the newly formed mangroves areas are in newly formed islands and sand bars. The trapping of sediments inside the estuarine region is due to the low freshwater output, caused by damming, and to decreasing annual rainfall and the increasing seawater forcing, both associated with global climate change.
These results found in Brazil are consistent with the reports made by the Brazilian Panel on Climate Change (PBMC 2013) where it was stated that alterations in water volume and sediment transport caused by significant changes in the watershed such as damming could cause different impacts, particularly mangrove area expansion, which may be further aggravated by global climate change. Notwithstanding, no significant changes in mangrove expansion poleward was evidenced in the southern latitudinal limit of mangroves in the South

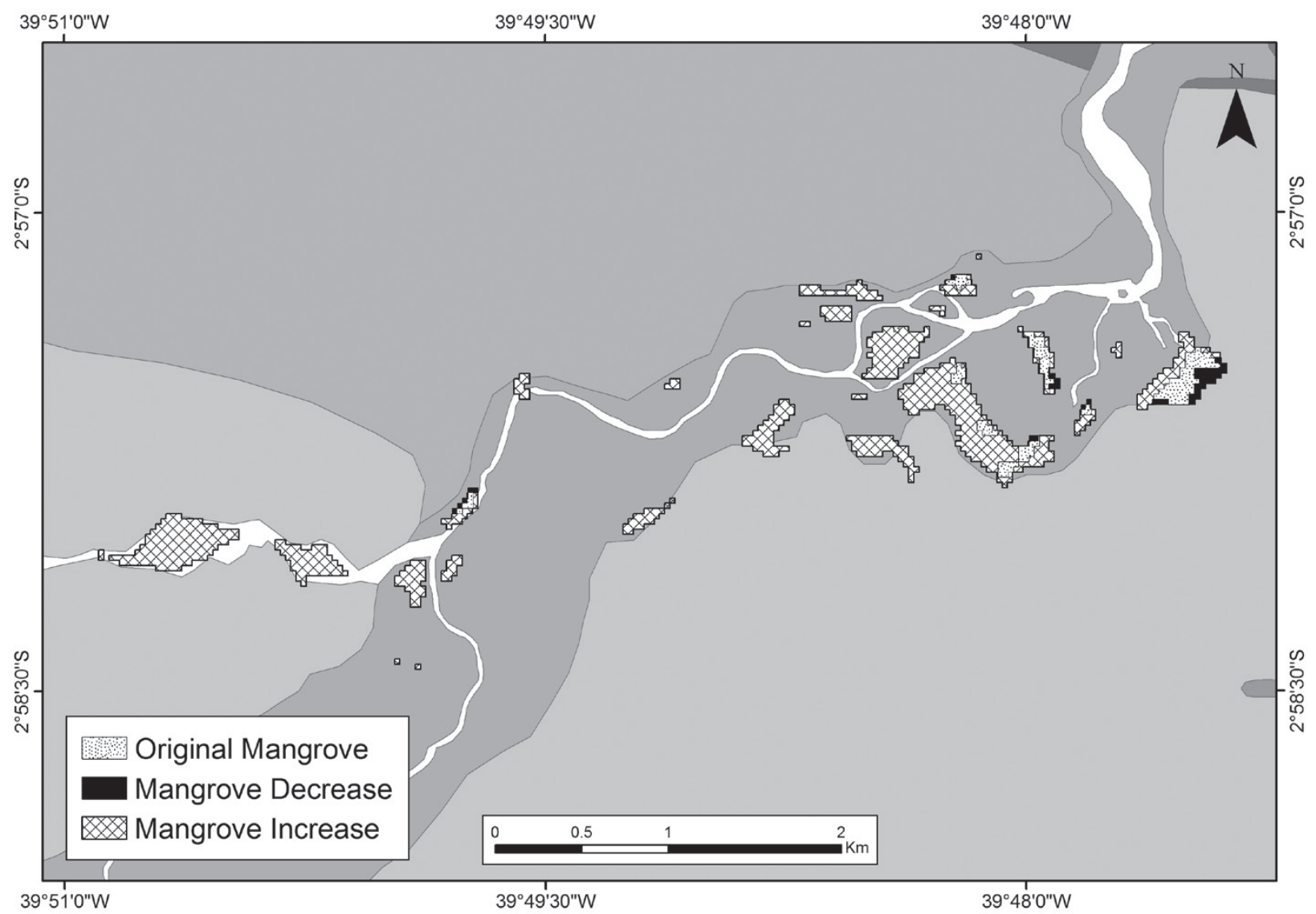

Figure 2 - Mapping of the Aracatimirim Estuary between the years 1993 and 2008 showing the mangrove spreading landward along the estuary.

Atlantic at Laguna, in the state of Santa Catarina. However, it is expected that in response to global warming, these forest may expand southward, most by Laguncularia racemosa, presently limited by hash climatic conditions in winter. This extension southward may result from an increase in air and ocean surface temperatures, a reduction in the frequency of frost events, stronger influence of the Brazil Current and a weakening of the Falkland Current (Soares et al. 2012). 
Based on the results available up until now, Figure 3 summarizes climate change impacts on Brazil's mangrove forests relative to area cover and distribution. Along the Northern Quaternary Coast, including the Amazon Macrotidal Mangrove Coast (AMMC) and the Northeastern semiarid coast, mangroves are mostly expanding landward, responding to sea-level rise and saline intrusion. At the Northeastern semiarid coast, reduced annual rainfall and damming of rivers enhance saline intrusion and accelerate mangrove expansion and landward migration. However, erosion of mangroves at the mouth of rivers and in subsiding deltaic island are locally counter balancing this trend.

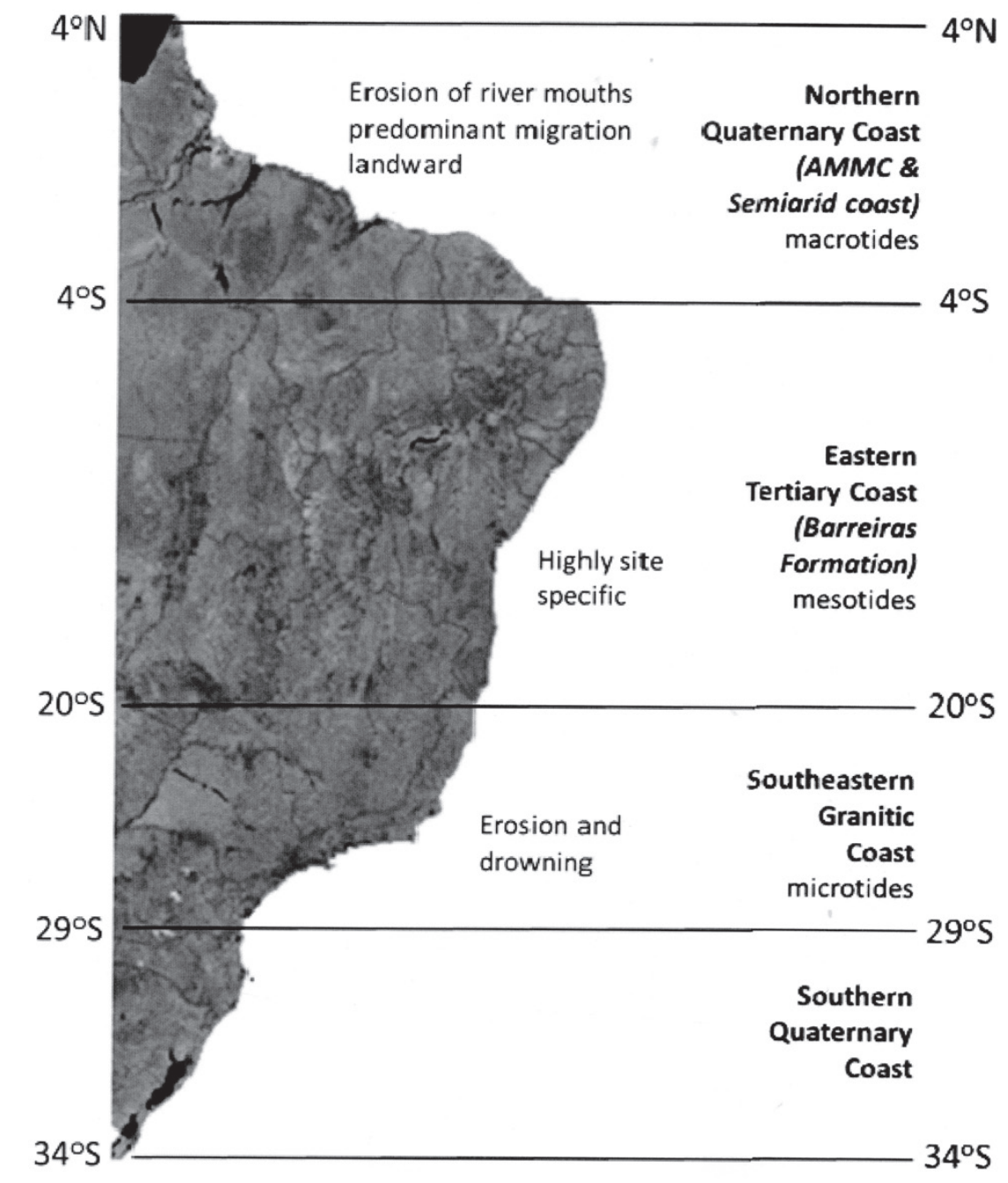

Figure 3 - A summary of identified mangrove responses to climate change along the Brazilian coast. Division and classification of the coast follow Lacerda et al. (2003) and Knoppers et al. (1999).

In contrast, along the Southeastern granitic coast, mangroves are disappearing faster due to being squeezed within the narrow coastal plains by sea-level rise and increasing frequency of extreme weather events, and further maximized by strong human pressure. At the southern tip of this zone, mangrove forests may expand their latitudinal range as temperature and atmospheric $\mathrm{CO}_{2}$ concentrations increase and the frequency of extreme cold events decrease, although as noted by Soares et al. (2012) 
no evidence exists on this southward movement of the local mangroves. Along the Eastern Tertiary Coast, little, if any data exists on the response of mangroves to climate change in relation to their cover area and distribution. The extremely high diversity of habitats and morphological setting of this coast and the enormous pressure from anthropogenic drivers may result in different responses at the local level; therefore, a general tendency cannot be presently depicted.

\section{DISCUSSION}

Worldwide mangroves have decreased by 35 to $86 \%$ depending on region, as a response to direct human pressure associated mainly with urban expansion and aquaculture (Duke et al. 2007). The major factor determining mangrove resilience to climate change-related sea level rise and warmer conditions are landward and poleward migration. Evidence of poleward migration suggests the upmost influence of the decrease in the frequency of extreme cold events. The further expansion and the survival of the ecosystem as a whole, however, are then mainly determined by local and regional factors. The local arid climate seems to be the case of the mangrove southern limit at the Pacific coast of South America, for example. Coastal topography and/or sediment accretion allowing the system as such to migrate landward and to maintain a suitable surface elevation is also involved in the poleward migration of mangroves. Consequently, coastal development, such as urban expansion and hard engineering coastal protection works, becomes even more important in this context.

Landward migration and change in area covered seems to be the major response of mangrove ecosystems to climate change, and depends on a numberofotherfactors determining theenvironmental setting, including rainfall and temperature variability (Woodroffe 1992, Esmali-Andargoli et al. 2009, Godoy and Lacerda 2014). Geomorphology of the coastal plain and sedimentation rates keeping pace with the rate of sea-level rise are key parameters controlling the magnitude of landward migration. In those environmental settings that have sufficient allochthonous sediment input and/or production and accumulation of organic matter and a suitable gradient of land surface elevation, sea level rise does not constitute a threat to mangroves. This generally holds true for the environmental settings that dominated by rivers, tides with abundant sediment supply and waves on prograding coasts (Woodroffe 1992). However, land uplift or subsidence, groundwater influx, vegetation and soil processes, and whether the coast is prograding or eroding also play important roles in determining the extent of the landward migration (Krauss et al. 2003, 2013, McKee et al. 2007, Lovelock et al. 2015).

Depending on the sediment input, mangroves accumulate peat or mud, which allows them to adjust to a rising sea level. The existing data show that sedimentation rates are frequently higher than current rates of sea-level rise facilitating migration landward (Alongi 2008, Lovelock et al. 2015). Locally, mangrove distribution and composition remain almost unaltered when the rates of sea level rise and sediment accumulation are almost similar. However, when the rate of sea level rise exceeds the rate of sediment accumulation, mangroves may be lost when the mean high tide becomes higher than the substrate elevation. This effect will be most vigorous in low-lying limestone islands with negligible allochthonous sediment input, as in some Caribbean islands (Ellison and Stodart 1991) and the deltas of a number of large tropical rivers where subsidence and disappearance of many deltaic islands are ongoing, as in the Sanderbans (Alongi 2015). Although Ellison and Stoddart (1991) suggested that mangroves will be lost at rates of sea level rise $>12 \mathrm{~cm}$ per 100 years, much lower than any of the conservative modeling of sea level rise (IPCC 2013), evidence from past Holocene sea level rise due to post-glacial rebound has shown mangrove expansion under much higher sea level rising rates. Maul and Martin (1993) have 
reported a relative sea level rise over the past 147 year of about $\sim 30 \mathrm{~cm}$ in Key West, South Florida, equivalent to $23 \mathrm{~cm}$ per 100 years, almost twice the critical maximum threshold suggested by Ellison and Stoddart (1991), without any significant collapse.

In the past 80 million years, mangroves have survived sea level changes of $120 \mathrm{~m}$ depending on local settings and sediment budgets, therefore, the present sea level rise threatens mangroves in some few places but in other places it provides opportunities (Alongi 2008). This, in turn, will similarly result in adverse effects for the filter function and biogeochemical transformation of substances in some places, while it will improve conditions in others.

Contrary to the local, direct impacts on mangroves, impacts from global climate change are much more difficult to forecast and model and therefore, more difficult to minimize. Furthermore, generic environmental legislation is not applicable at this spatial and temporal scales and mangroves have been nearly absent from international global discussion, as well as regional panels on climate change. Besides, reliable results on this subject are still scarce, creating further difficulties in understanding the magnitude and consequences of the impacts. With respect to climate change, it is rather difficult to assess the indirect consequences for mangroves in terms of carbon and nutrient transformation and accumulation. Since mangroves represent a significant sink of carbon at the continent-ocean interface, their response to climate change may result in a negative or positive feedback to this change.

\section{CONCLUSIONS}

The existing climate change scenarios point to temperature increase and a rise in sea level as the most important factors directly affecting the distribution of mangroves and strongly suggest an expansion of these forests (Field 1995, Alongi 2008). The accumulating observations lead us to conclude that the mangroves cannot only endure within the new environmental conditions imposed by climate change but also, in some places, will flourish. Understanding how human activities and a changing climate are likely to interact and affect the delivery of services by these ecosystem, is of the utmost importance to the present decisionmaking process affecting the health of marine and coastal systems and their ability to sustain future generations. Regarding mangrove's response to global climate change, the studies analyzed in this review showed that although there are areas where mangroves will suffer due to environmental changes, mostly in oceanic islands and deltas of a number of large tropical rivers, and those coastal sites enclosed by steep slopes that are at risk of being drowned by the advancing sea, in most regions mangrove area will increase responding to increasing sea level, decreasing rainfall and saline intrusion. Under such environmental setting mangroves respond to changing conditions of waves and salinity by migrating to places farther inland, often at the expense of other plant species and their ability to take advantage of conditions of warmer winters by expanding their limits toward higher latitudes.

Human interventions involving resource exploitation, river basin processes and engineering works for shoreline protection, primarily aimed to adapt to global change, rather increase vulnerability of mangroves, diminishing mitigating options to address the adverse consequences of climate change. In fact adaptation options to enhance mangrove resistance and resilience to climate change suggests that it is the humaninduced degradation of mangroves that needs to be addressed. Thus, regional monitoring to improve the understanding of mangroves' response, training and capacity building programs aimed towards the public and decision makers, towards an increased awareness of the value of mangrove ecosystem goods and services, will contribute to decreasing 
the risk of mangrove loss related to climate change. The future of mangroves therefore, largely depends on the degree of human interventions and their interactions with climate-related changes.

\section{ACKNOWLEDGMENTS}

This study was supported by Conselho Nacional de Desenvolvimento Científico e Tecnológico (CNPq) through the INCT-TMCOcean Proc. No. 573.601/2008-9 and Coordenação de Aperfeiçoamento de Pessoal de Nível Superior (CAPES - Marine Science Program Proc. No. 533/2010). Thanks are due to the many colleagues within the framework of the Rede Clima-SubRede Oceanos, from the Ministry of Science, Technology and Innovation of Brazil, for their fruitful insights and to an anonymous reviewer who greatly improved a former version of this manuscript.

\section{RESUMO}

Manguezais funcionam como proteção natural para a linha da costa em casos de erosão e inundação, provendo importantes serviços ambientais. Devido à distribuição geográfica desse habitat na interface continente-oceano, é muito provável que sofra sérios impactos oriundos das mudanças climáticas, potencializados por atividades humanas na zona costeira. Esse trabalho revisa os resultados de estudos realizados nos últimos 25 anos sobre as respostas observadas dos manguezais às alterações ambientais causadas tanto por alterações climáticas. Foram levados em consideração 104 estudos de caso e de modelagem no mundo todo. A maioria desses estudos foi publicada depois do ano 2000 como um reflexo do relatório publicado pelo IPCC em 1997. Apesar de muitos estudos mostrarem uma diminuição global da área de manguezais no mundo devido à pressão antrópica direta, vários outros mostraram que, localmente, uma variedade de habitats de manguezal está se expandindo como uma resposta à mudança climática global. Em todo o mundo, uma migração em direção aos polos está ampliando os limites latitudinais de manguezais devido a invernos mais quentes, e a diminuição de eventos de baixas temperaturas extremas, enquanto nas baixas planícies costeiras os manguezais estão migrando continente adentro devido ao aumento do nível do mar, como observado para o litoral nordeste brasileiro. Levando em consideração apenas as alterações climáticas globais, os manguezais irão exibir uma resposta positiva na maior parte de sua área de distribuição. Em algumas áreas, no entanto, como ilhas oceânicas baixas, como no oceano pacífico e no Caribe, e zonas costeiras restritas, como no litoral sudeste do Brasil, os manguezais mais provavelmente não sobreviverão.

Palavras-chave: clima, manguezal, limites, migração.

\section{REFERENCES}

Adams JB, Colloty BM and Bate GC. 2004. The distribution and state of mangroves along the coast of Transkei, Eastern Cape Province, South Africa. Wetl Ecol Manag 12: 531-541.

ALONGI DM. 2008. Mangrove forests: resilience, protection from tsunamis and response to global climate change. Estuar Coast Shelf Sci 76: 1-13.

AlongI DM. 2015. The Impact of Climate Change on Mangrove Forests. Curr Climate Change Rep 1: 30-39.

BARTH OM, SÃo-Thiago LEU AND BARRos MA. 2006. Paleoenvironment interpretation of a 1760 years B.P. old sediment in a mangrove area of the Bay of Guanabara, using pollen analysis. An Acad Bras Cienc 78: 227-229.

Bastos AC, Vilela CG, QuARESMa VS AND Almeida FK. 2010. Mid- to Late-Holocene estuarine infilling processes studied by radiocarbon dates, high resolution seismic and biofacies at Vitoria Bay, Espirito Santo, Southeastern Brazil. An Acad Bras Cienc 82: 761-770.

BEDIN T. 2001. The progression of a mangrove forest over a newly formed delta in the Umhlatuze Estuary, South Africa. S Afr J Bot 67: 433-438.

Behling H, Cohen MCL And LARA RJ. 2001. Studies on Holocene mangrove ecosystem dynamics of the Bragança Peninsula in north-eastern Para, Brazil. Palaeoecol Palaeogeogr Palaeoclimatol 167: 225-242.

Behling H, COHEN MCL AND LARA RJ. 2004. Late Holocene mangrove dynamics of Marajo Island in Amazonia, northern Brazil. Veg Hist Archeobot 13: 73-80.

CAstro DF, Oliveira PE, Rossetti DF AND PESSENDA LCR. 2013. Late Quaternary landscape evolution of northeastern Amazonia from pollen and diatom records. An Acad Bras Cienc 85: 35-55.

Cavanaugh KC, Kellner JR, Forde AJ, Gruner DS, PARKer JD, Rodriguez W AND FEller IC. 2014. Poleward expansion of mangroves is a threshold response to decreased frequency of extreme cold events. Proc Nat Acad Sci 111: 723-727. 
CLÜSENER M AND BRECKLE SW. 1987. Reasons for the limitation of mangrove along the west coast of northern Peru. Vegetatio 68: 173-177.

COGERH. 2015. Portal hidrológico do Ceará. Available at: http://www.hidro.ce.gov.br/. Accessed in 16 January 2015.

COPERTINO MS. 2011. Add coastal vegetation to the climate change critical list. Nature 473: 255.

CUNHA-LIGNON M, MAHIQUES MM, SCHAEFFER-NOVELli Y, Rodrigues M, Klein DA, Goya SC, Menghini RP, Tolentino CV, Cintron-Molero G AND DAhdouhGUEBAS F. 2009. Analysis of mangrove forest succession, using cores: a case study in the Cananeia-Iguape coastal system, São Paulo, Brazil. Braz J Oceanogr 57: 161-174.

Dai A, Qian T, TREnBerth KE AND Millman JD. 2009. Changes in Continental Freshwater Discharge from 1948 to 2004. J Clim 22: 2773-2779.

Dias FJS, CASTRO BM AND LACERDA LD. 2013. Continental shelf water masses off Jaguaribe River $\left(4^{\circ} \mathrm{S}\right)$ - Northeastern, Brazil. Cont Shelf Res 66: 123-135.

Di Nitto D, Neukermans G, Koedam N, Defever H, PATTYN F, KAIRO JG AND DAHDOUH-Guebas F. 2014. Mangroves facing climate change: landward migration potential in response to projected scenarios of sea level rise. Biogeosciences 11: 857-71.

Doyle TW, Krauss KW, ConNer WH ANd From AS. 2010. Predicting the retreat and migration of tidal forests along the northern Gulf of Mexico under sea-level rise. For Ecol Manag 250: 770-777.

DUKE NC ET AL. 2007. A world without mangroves? Science 317: 41-42.

ELLISON JC AND StOdDART DR. 1991. Mangrove ecosystem collapse during predicted sea-level rise: Holocene analogues and implications. J Coast Res 7: 151-165.

Eslami-Andargoli L, DALE PER, SiPe N AND Chaseling J. 2009. Mangrove expansion and rainfall patterns in Moreton Bay, Southeast Queensland, Australia. Estuar Coast Shelf Sci 85: 292-298.

FAO. 2007. The world's mangroves 1980-2005. FAO Forestry Paper. Rome, 77 p.

FIELD CD. 1995. Impact of expected climate change on mangroves. Hydrobiol 295: 75-81.

Gilman E, Ellison J AND COLEMAN R. 2007. Assessment of mangrove response to projected relative sea-level rise and recent historical reconstruction of shoreline position. Environ Monit Assess 124: 105-130.

GILMAN E ET AL. 2006. Pacific Island mangroves in a changing climate and rising sea. UNEP Regional Seas Reports and Studies No. 179. UNEP, Nairobi, 58 p.

Gilman EL, Ellison J, Duke NC AND Field CD. 2008. Threats to mangroves from climate change and adaptation options: A review. Aquat Bot 89: 237-250.

Giri C, OChieng E, TIESZEN LL, Zhu Z, Singh A, LOVELAND T, MASEK J AND DUKE N. 2011. Status and distribution of mangrove forests of the world using Earth observation satellite data. Global Ecol Biogeogr 20: 154-159.
Giri C, Pengra B, Zhu Z, Singh A And Tieszen L. 2007. Monitoring mangrove forest dynamics of the Sundarbans in Bangladesh and India using multi-temporal satellite data from 1973-2000. Estuar Coast Shelf Sci 73: 91-100.

Giri C, Zhu Z, Tieszen LL, Singh A, Gillette S AND KELMELIS JA. 2008. Mangrove forest distributions and dynamics (1975-2005) of the tsunami-affected region of Asia. J Biogeogr 35: 519-528.

GODOY MDP AND LACERDA LD. 2014. River-island response to land-use change within the Jaguaribe River, Brazil. J Coast Res 30: 399-410.

Guimarães JTF, COHEN MCL, FranÇA MC, LARA RJ AND BeHLing H. 2010. Model of wetland development of the Amapá coast during the late Holocene. An Acad Bras Cienc 82: 451-465.

HaK J, LÓPEZ-Medellín X, Beltrán JM, Josse C, Stein B AND White R. 2008. Changes in Mangrove Habitat in Baja California Sur from 1986 to 2001. Natureserve, Arlington, USA, Available at: http://research.fit.edu/ sealevelriselibrary/documents/doc mgr/472/Baja California_Sur_Mangrove_Changes_1986-2001_-_Hak_ et_al._2008.pdf. Accessed in 15 January 2015.

Herz R. 1991. Manguezais do Brasil. São Paulo. Instituto Oceanográfico, Universidade de São Paulo, 227 p.

IPCC. 1997. The Regional Impacts of Climate Change: An Assessment of Vulnerability. Cambridge University Press, United Kingdom, 517 p.

IPCC. 2013. Climate change 2013: The physical science basis. Contribution of Working Group I to the Fifth Assessment Report of the Intergovernmental Panel on Climate Change. Cambridge University Press. United Kingdom and New York, $1535 \mathrm{p}$.

Knoppers BA, EKAU W AND Figueiredo AG. 1999. The coast and shelf of east and northeast Brazil and material transport. Geo-Marine Lett 19: 171-178.

KraUsS KW, AlLEN JA AND CAHOON DR. 2003. Differential rates of vertical accretion and elevation change among aerial root types in Micronesian mangrove forests. Estuar Coast Shelf Sci 56: 251-259.

Krauss KW, Mckee KL, Lovelock CE, Cahoon R, SAINTILAN N, REEF R AND CHEN L. 2013. How mangrove forests adjust to rising sea level. New Phytol 202: 19-34.

Lacerda LD, AraúJo DSD AND Maciel NC. 1993. Dry coastal ecosystems of the tropical Brazilian coast. In: Van Der Maarel E (Eds), Dry Coastal Ecosystems of the World. Vol. 2B, Chapter 32, Elsevier Publ. Co., Amsterdam, p. 477-493.

LACERDA LD, Dias FJS, MARINS RV, SOARES TM, GODOY JM AND GODOY MLDP. 2013. Pluriannual watershed discharges of $\mathrm{Hg}$ into tropical semi-arid estuary of the Jaguaribe River, NE Brazil. J Braz Chem Soc 24: 1719-1731.

LACERDA LD, Menezes MOT AND Molisani MM. 2007. Changes in mangrove extension at the Pacoti River estuary, CE, NE Brazil due to regional environmental changes between 1958 and 2004. Biota Neotrop 7(3): 1-7.

LAURENCE WF ET AL. 2011. The 10 Australian ecosystems most vulnerable to tipping points. Biol Conser 144: 1472-1480. 
LONG J, NAPTON D, GIRI C AND GRAESSER J. 2014. A mapping and monitoring assessment of the Philipinne's mangrove forests from 1990 to 2010. J Coast Res 30: 260-271.

LÓPEZ-MEDELlíN X, EZCURRA E， GONZÁlEZ-ABRAHAM C, HAK J, SANTIAGO LS AND SICKMAN JO. 2011 Oceanographic anomalies and sea-level rise drive mangroves inland in the Pacific coast of Mexico. J Veget Sci 22: 143-151.

Lovelock CE, Adame MF, Bennion V, Hayes M, ReEF R, SANTINI M AND CAHOON DR. 2015. Sea level and turbidity controls on mangrove soil surface elevation change. Estuar Coast Shelf Sci 153: 1-9.

LOVELOCK CE, FELlER IC, Ellis J, SCHWARZ AM, HANCOCK N, NiCHOLS P AND SORRELL B. 2007. Mangrove growth in New Zealand estuaries: the role of nutrient enrichment at sites with contrasting rates of sedimentation. Oecologia 153: 633-641.

LOVELOCK CE, SORRELl BK, HANCOCK N, HUA Q AND SWALES A. 2010. Mangrove forest and soil development on a rapidly accreting shore in New Zealand. Ecosystems 13: 437-451.

Maia LP, Lacerda LD, Monteiro LHU and SouZa GM. 2006. Atlas dos manguezais do Nordeste do Brasil: avaliação das áreas de manguezais dos estados do Piaú, Ceará, Rio Grande do Norte, Paraíba e Pernambuco. SEMACE, $150 \mathrm{p}$.

MaUl GA AND MARTin DM. 1993. Sea level rise at Key West, Florida, 1846-1992: America's longest instrument record? Geophys Res Let 20: 1955-1958.

McKeE KL, CAHoon DR and Feller IC. 2007. Caribbean mangroves adjust to rising sea level through biotic controls on change in soil elevation. Global Ecol Biogeogr 16: $545-556$

McKeE KL, Mendelssohn IA And Maternes MD. 2004 Acute salt marsh die-back in the Mississippi River deltaic plain: a drought-induced phenomenon? Global Ecol Biogeogr 13: 65-73.

Medina E, Fonseca H, BARBoza F And Francisco M. 2001 Natural and man-induced changes in a tidal channel mangrove system under tropical semiarid climate at the entrance of the Maracaibo Lake (Western Venezuela). Wetl Ecol Manag 9: 233-243.

MeEder JF, Ross MS AND Ford RG. 1993. Mangrove ecosystem expansion in South Florida under conditions of accelerating rate of sea level rise: Results of conceptual depositional and spatial models, In: Brunn PER (Ed), Proceedings Hilton Head Island. SC, USA. International Coastal Symposium 2: 431-445.

NASCIMENTO JR WR, SOUZA-FILHO PW, Proisy C, LUCAS RM AND RoSENQVIST A. 2013. Mapping changes in the largest continuous Amazonian mangrove belt using object-based classification of multisensor satellite imagery. Estuar Coast Shelf Sci 117: 83-93.

NGUYEN H. 2014. The relation of coastal mangrove changes and adjacent land-use: A review in Southeast Asia and Kien Giang, Vietnam. Ocean Coast Manag 90: 1-10.
Nicholls RJ AND CAZENAVE A. 2010. Sea-level rise and its impact on coastal zones. Science 328: 1517-1520.

PACHAURI RK. 2015. Climate Change 2014 Synthesis Report. Cambridge University Press, Cambridge, United Kingdom and New York, NY, USA.

PBMC. 2013. Base científica das mudanças climáticas. Contribuição do Grupo de Trabalho 1 ao Primeiro de Avaliação Nacional do Painel Brasileiro de Mudanças Climáticas. Sumário Executivo do GT2. PBMC, Rio de Janeiro, Brasil.

PERRY CL AND Mendelssohn IA. 2009. Ecosystem effects of expanding populations of Avicennia Germinans in a Louisiana salt marsh. Wetlands 29: 396-406.

POLIDORO BA ET AL. 2010. The loss of species: mangrove extinction risk geographic areas of global concern. PLoS ONE 5: 1-10.

QUisthoudt K, AdAmS J, RAJKARAN A, DAHDOUH-GUEBAS F, KoEDAM N AND RANDIN CF. 2013. Disentangling the effects of global climate and regional land-use change on the current and future distribution of mangroves in South Africa. Biodiver Conser 22: 1369-1390.

RAHU A, DAS S, BANERJEe K AND Mitra A. 2012. Climate change impacts on Indian Sunderbans: a time series analysis (1924-2008). Biodiver Conser 21: 1289-1307.

RAJKARAN A, ADAMS J AND TAYLOR R. 2009. Historic and recent (2006) state of mangroves in small estuaries from Mlalazi to Mtamvuna in KwaZulu-Natal, South Africa. South Forests 71: 287-296.

Rao M, Htun S, Platt SG, Tizard R, Poole C, Myint T AND WATSON JEM. 2013. Biodiversity conservation in a changing climate: A review of threat and implications for conservation planning in Myanmar. Ambio 42: 789-804.

RosS MS, FLYNN LJ AND O'BRIEN JJ. 1991. Has $20^{\text {th }}$ century sea level rise caused the migration of Florida Keys plant communities? Am J Bot 78: 46.

Ross MS, MeEder JF, SAH JP, RuIZ PL AND TELESNICKI GL. 2000. The southeast saline Everglades revisited: 50 years of coastal vegetation change. J Veget Sci 11: 101-112.

Ross MS, O’Brien JJ, FORD RG, ZHANG K AND MORKILL A. 2009. Disturbance and the rising tide: the challenge of biodiversity management on low-island ecosystems. Front Ecol Environ 7: 471-478.

RubÉN L, SZlafsZTEIN C, COHEN M, BERGER U AND GLASER M. 2002. Implication of mangroves dynamics for private land use in Bragança, North Brazil: a case study. J Coast Conser 8: 97-102.

SAINTILAN N, WILSON N, ROGERS K, RAJKARAN A AND KrAUSS KW. 2014. Mangrove expansion and salt marsh decline at mangrove poleward limits. Global Change Biol 20: 147-157.

SANTOS LCM, Matos HR, SCHAEFFER-NOVELli Y, CUNHALIGNON M, BITENCOURT MD, KOEDAM N, DAHDOUHGUEBAS FAND SCHAEFFER-NOVELLIY. 2014. Anthropogenic activities on mangrove areas (São Francisco River Estuary, Brazil Northeast): a GIS-based analysis of CBERS and SPOT images to aid in local management. Ocean Coast Manag 89C: 39-50. 
SCAVIA D ET AL. 2002. Climate change impacts on U.S. coastal and marine ecosystems. Estuaries 25: 149-164.

SCHAEFFER-NOVElli Y, CinTRON-MOLERO G AND SOARES MLG. 2002. Mangroves as indicators of sea level change in the muddy coasts of the world. In: Healy TJ, Yang T and Healy JA (Orgs), Muddy Coasts of the World: Processes, Deposits and Function. Elsevier Science BV, p. 245-262.

SHEARMAN P. 2010. Recent change in the extent of mangroves in the Northern Gulf of Papua, Papua New Guinea. Ambio 39: 181-189.

SHEARMAN P, BRYAN J AND WALSH JP. 2013. Trends in deltaic change over three decades in the Asia-pacific region. $J$ Coast Rese 29: 1169-1183.

SMith III TJ, Foster AM, TILING-RAnge G AND Jones JW. 2013. Dynamics of mangrove-marsh ecotones in subtropical coastal wetlands: Fire, sea-level rise, and water levels. Fire Ecol 9: 66-77.

SNedAKer SC, MeEder JF, Ross MS AND Ford GR. 1994. Discussion on Ellison JC and Stoddart DR (1991). Mangrove ecosystem collapse during predicted sea-level rise: Holocene analogues and implications. J Coast Res 7: 151-165.

SOARES MLG, Estrada GCD, FERNANDEZ V AND TOGNELla MMP. 2012. Southern limit of the Western South Atlantic mangroves: Assessment of the potential effects of global warming from a biogeographical perspective. Estuar Coast Shelf Sci 101: 44-53.

SouzA FiLHo PW. 2005. Costa de manguezais de macro maré da Amazônia: Cenários morfológicos. Braz J Geophys 23: 427-435.

SoUZA FILHO PWM AND PARAdELla WR. 2003. Use of synthetic aperture radar for recognition of Coastal Geomorphological Features, land-use assessment and shoreline changes in Bragança coast, Pará, Northern Brazil. An Acad Bras Cienc 75: 341-356.

SPALDING M, BLASCO F AND FIELD CD. 1997. World atlas of mangrove. The International Society for Mangrove Ecosystems, Okinawa, Japan, 178 p.

SPALding M, Kainuma M AND Collins L. 2010. World atlas of mangroves. Earthscan. UK and USA, 336 p.

SteVEns PW, Fox SL AND Montague CL. 2006. The interplay between mangroves and saltmarshes at the transition between temperate and subtropical climate in Florida. Wetl Ecol Manag 14: 435-444.
Stokes DJ, HeAly TR AND COOKE PJ. 2010. Expansion dynamics of monospecific, temperate mangroves and sedimentation in two embayments of a barrier-enclosed lagoon, Tauranga Harbour, New Zealand. J Coast Res 261: 113-122.

TAYlor M, RAVILIOUS C AND GREEN EP. 2003. Mangroves of East Africa. UNEP-WCMC, Cambridge, UK, 24 p.

Tessler MG AND MAHIQues MM. 1998. Erosional and depositional processes on the southern coast of the state of São Paulo: A case study of Cananéia-Iguape system. An Acad Bras Cienc 70: 267-275.

TOLEDO MB AND BUSH MB. 2008a. A Holocene pollen record of savanna establishment in coastal Amapá. An Acad Bras Cienc 80: 341-351.

Toledo MB AND Bush MB. 2008b. Vegetation and hydrology changes in Eastern Amazonia inferred from a pollen record. An Acad Bras Cienc 80: 191-203.

UNEP-UNESCO. 1993. Impacts of expected climate change on mangroves. UNEP-UNESCO Task Team Report of the First Meeting, Rio de Janeiro 1-3 June, 1992. Unesco Rep Mar Sci 61: 1-20.

USGS. 2004. Global change impacts on mangrove ecosystems. Fact Sheet 2004, 312, 5 p.

VALIELA I, BOWEN JL AND YORK JK. 2001. Mangrove forest: one of the world's threatened major tropical environments. BioScience 51: 807-815.

WARD CJ AND STEINKE TD. 1982. A note on the distribution and approximate areas of mangroves in South Africa. S Afri J Bot 3: 51-53.

Williamson GJ AND BogGS GS. 2011. Late $20^{\text {th }}$ century mangrove encroachment in the coastal Australian monsoon tropics parallels the regionals increase in woody biomass. Reg Environ Change 11: 19-27.

WiLtON KM. 2002. Coastal wetland habitat dynamics in selected New South Wales estuaries. PhD thesis, Australian Catholic University, 329 p.

WoODROFFE CD. 1992. Mangrove sediments and geomorphology. In: Robertson AI and Alongi DM (Eds), Tropical Mangrove Ecosystems. AGU, Washington, Coastal and Estuarine Studies 41: 7-41. 
